\title{
Late Bronze Age in Alcáçova de Santarém (Portugal)
}

\author{
La Edad del Bronce Final en Alcáçova de Santarém (Portugal)
}

\author{
Ana Margarida Arruda (*) \\ Elisa de Sousa (*)
}

\begin{abstract}
The field work that took place in the restaurant area in Jardim das Portas do Sol (Alcáçova de Santarém) recovered well-preserved archaeological layers dated to the Late Bronze Age, lying directly underneath the Iron Age phase. The excavation made it possible to collect an important set of ceramics that incorporate printed and incised decoration, which can be easily decoration related to the Cogotas 1 cultural background. Burnished decorations, with grooves on the inner surface and outer strips, are less common. The formal repertoire does not deviate from what is known about the Late Bronze Age in central and southern Iberian Peninsula. The data allow us to propose a chronology centered in the early $1^{\text {st }}$ millennium $\mathrm{BCE}$ for this occupation.
\end{abstract}

\section{RESUMEN}

Durante los trabajos de campo, realizados en el área del restaurante del Jardim das Portas do Sol, se documentaron, por primera vez en Alcáçova de Santarém, niveles conservados del final de la Edad del Bronce, inmediatamente infrapuestos a los de la Edad del Hierro. Su excavación permitió recoger un conjunto de materiales cerámicos que incorpora varios fragmentos decorados por impresión e incisión, que pueden ser fácilmente relacionados con el universo cultural de Cogotas 1. Las decoraciones bruñidas con surcos en la superficie interna $y$ con franjas al exterior son mucho menos frecuentes. El repertorio formal no difiere del conocido para el Bronce Final del centro y sur de la Península Ibérica. Los datos

(*) UNIARQ-Centro de Arqueologia da Universidade de Lisboa, Faculdade de Letras, Alameda da Universidade. 1600214 Lisboa. Portugal. E-mail: a.m.arruda@letras.ulisboa.pt; sousa@campus.ul.pt

Received: 18-III-2014; accepted: 14-IV-2014. permiten proponer ua cronologia del inicio del 1 milenio a.n.e. (siglo IX) para esta ocupación.

Key words: Santarém; Late Bronze Age; Cogotas 1; Printed and incised ceramics.

Palabras clave: Santarém; Bronze Final; Cogotas 1; Cerámica impresa e incisa.

\section{INTRODUCTION}

The Alcáçova de Santarém is on a plateau of about $50.000 \mathrm{~m}^{2}$ overlooking the Tagus (Fig. 1). It has great natural defensibility and occupies a key strategic position that visually dominates extensive areas of the river valley. Its coordinates are $39^{\circ} 4^{\prime} 01^{\prime \prime} \mathrm{N} ; 8^{\circ} 40^{\prime} 30^{\prime \prime} \mathrm{W}$. The site has a well-documented sequence of occupation from the Iron Age to the present (Arruda and Viegas 2002).

The Bronze Age occupation of Alcáçova de Santarém was always intuited, and even assumed to exist, although the related data had always been too scarce and faint for its definition (Arruda 1999-2000). This was because the archaeological work at the site was carried out within the constraints of "urban archeology". The excavated areas were small and the overlay of Iron Age, Roman, medieval and modern occupations often prevented one from reaching the deepest levels (Arruda and Viegas 2002). And when such levels were reached, the excavated area was usually quite restricted and yielded reduced evidence for the associated material culture. On other occasions, as, for example, in 1999-2000, it became 


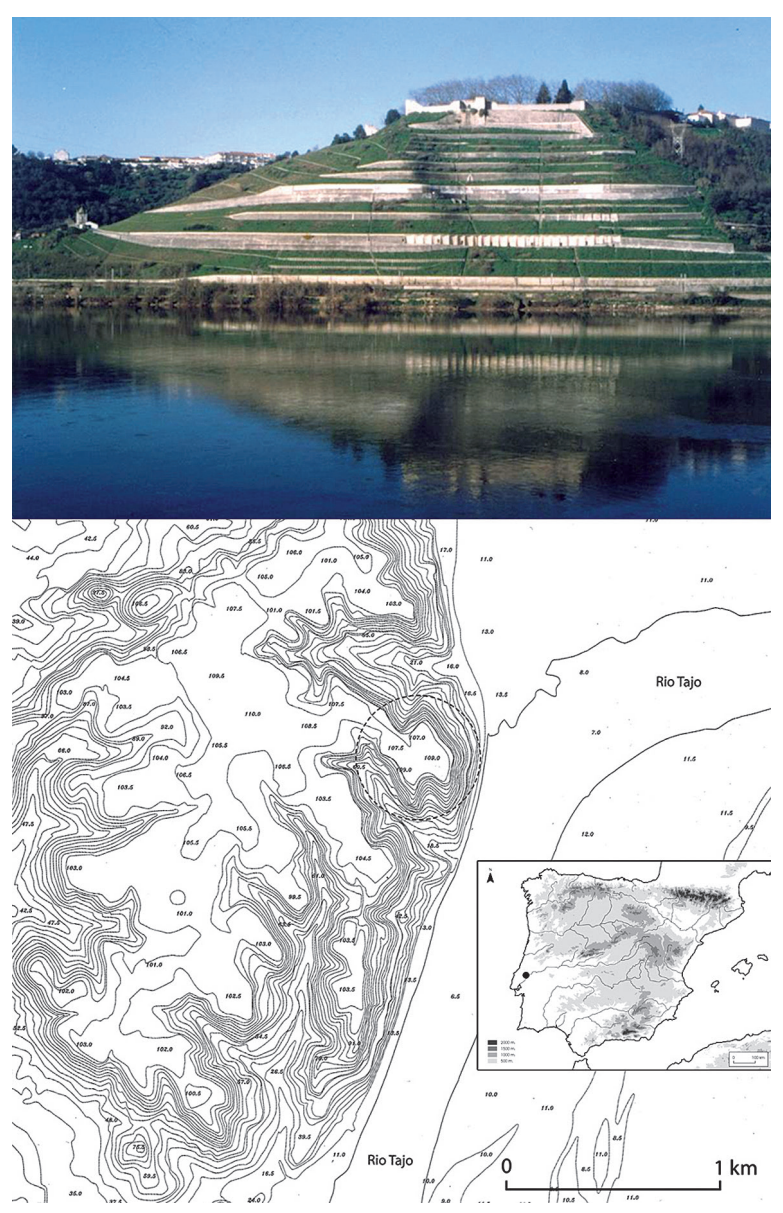

Fig. 1. Alcáçova de Santarém view from the Tagus. Location of Santarém in the Iberian Peninsula (cartographic base from the authors).

possible to excavate a relatively large area, but the decision to consolidate the Roman imperial occupation prevented the excavation from reaching the lower archeological levels. Moreover, the long occupation of the site also often entailed the destruction of ancient levels by newer constructions.

On some occasions it was possible to identify levels where all the pottery was handmade, but these involved small areas. Furthermore, in the earliest Iron Age strata of occupation the percentage of wheel made pottery rarely exceeded $20 \%$ (Arruda 1993, 1999-2000, 2005). This impeded clear characterization of Alcáçova de Santarém's Late Bronze Age.
However, in 2011, an excavation that covered a surface of circa $80 \mathrm{~m}^{2}$, carried out at the Portas do Sol restaurant, finally allowed us to identify, without a shadow of doubt, Late Bronze Age occupational levels, in some cases associated with archaeological structures. Here, Islamic and Roman pits did not reach the lower strata that retained the oldest traces of occupation. Note also that above them we were able to detected Iron Age levels that also avoided the effects of subsequent occupations.

\section{THE EXCAVATION OF THE RESTAURANT JARDIM DAS PORTAS DO SOL}

The 2001 excavations at the Jardim das Portas do Sol had the scientific coordination of one of us (AMA) and Catarina Viegas. The field work was directed by Rui Almeida, Rui Mataloto, Artur Rocha and Susana Estrela, applying the methodological principles proposed by Philip Barker and Edward Harris. All sediments were sieved.

The excavated area of approximately $80 \mathrm{~m}^{2}$ revealed a complex stratigraphic sequence that integrates modern, medieval, Roman, Iron Age, and, finally, Late Bronze Age occupation phases. In this last phase we have identified three distinct moments, corresponding to sequential occupations of the area that may not have a clear chronological expression.

The earliest sub-phase is the one in the worst condition. We only found part of what appears to be a stone structure (S.U. [322]) with irregular outlines and no diagnostic artifacts (Fig. 2A).

The next moment incorporates a primary occupation layer (S.U. [317]), associated with two combustion areas (S.U. [318] and S.U. [311]/[312]) and a post-hole (S.U. [319]/[320]) (Fig. 2B).

Above this, we detected another pavement (S.U. [309]/[310]), also associated with two postholes (S.U. [315]/[316] and S.U. [313]/[314]), partially covered by a layer of rubble (S.U. [308]). This occupational subphase is covered by another stratum (U.S. [294]) that continues to have Late Bronze Age material (Figs. 3 and 4). 


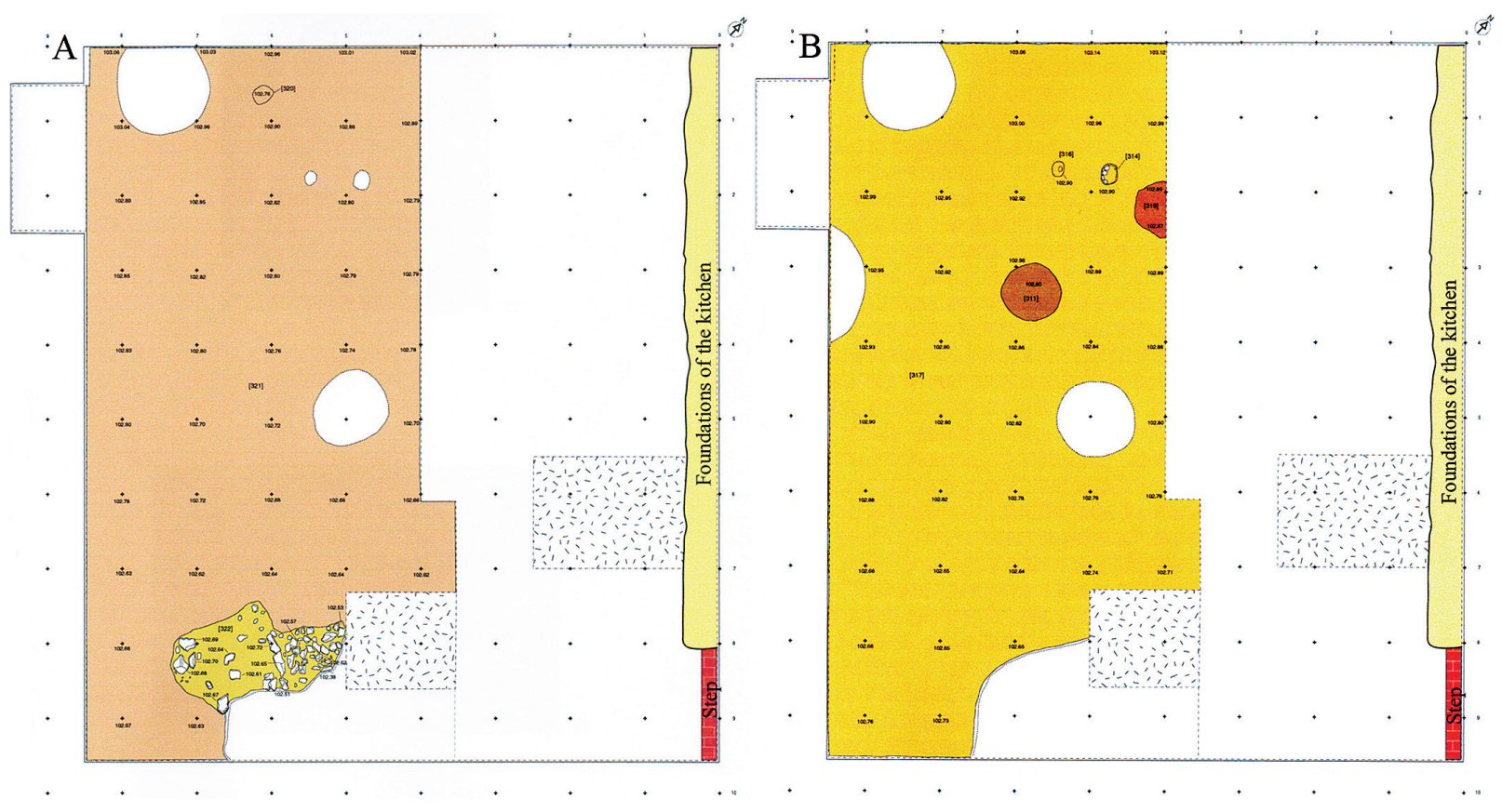

Fig. 2. Alcáçova de Santarém: A. Plan of the geological substrate, S.U. [321] and structure S.U. [322] (1m x 1m grid); B. Plan of pavement S.U. [317], combustion areas S.U. [311] / [318] and post-holes S.U. [314] / [316] (1m x 1m grid).

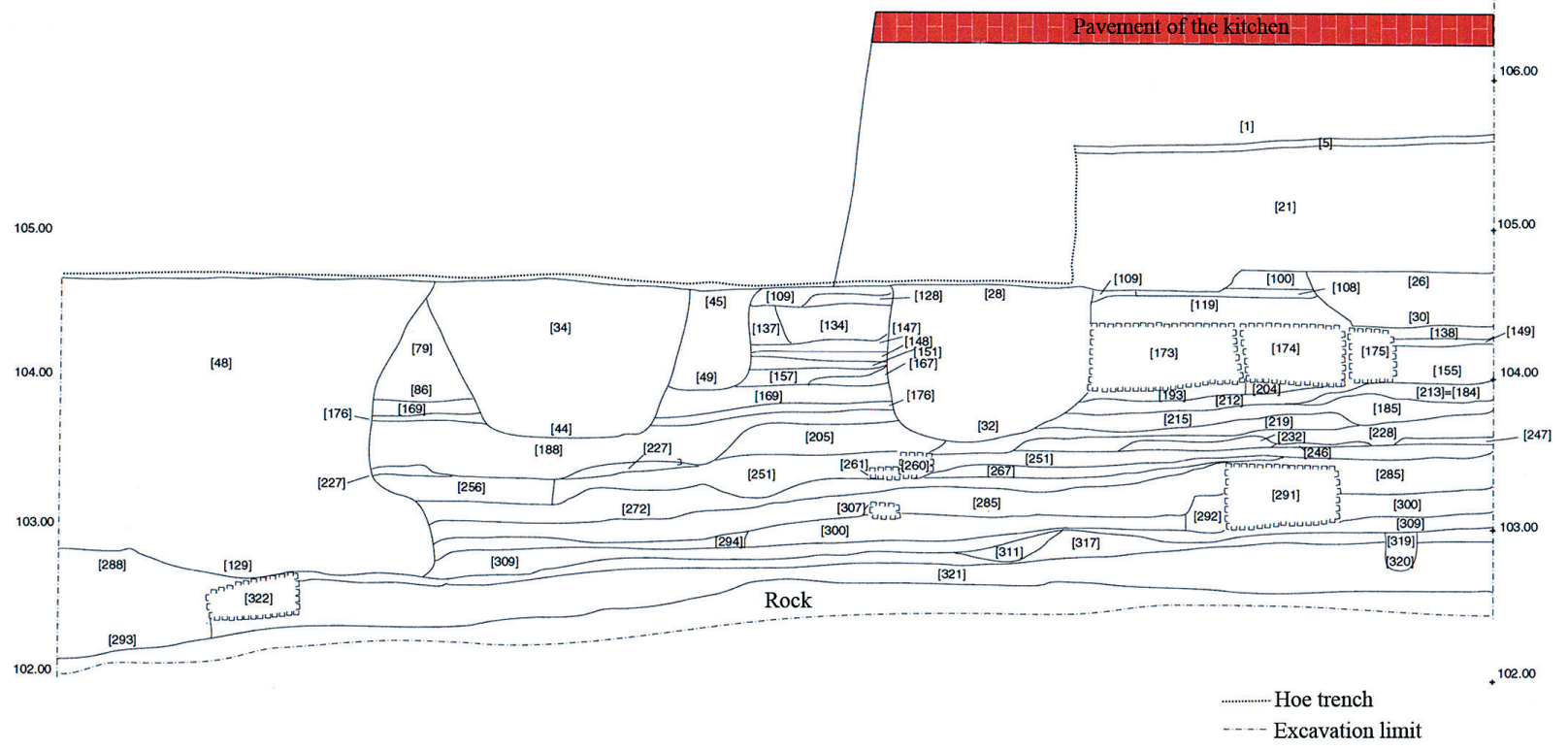

Fig. 3. Alcáçova de Santarém. Cross section $\mathrm{S} / \mathrm{N}$ of the excavated Sector 2, $6 \mathrm{~m}$ below benchmark. Scale 1 to 9 meters.

Trab. Prehist., 72, N. ${ }^{\circ}$ 1, enero-junio 2015, pp. 176-187, ISSN: 0082-5638 doi: $10.3989 /$ tp. 2015.12150 


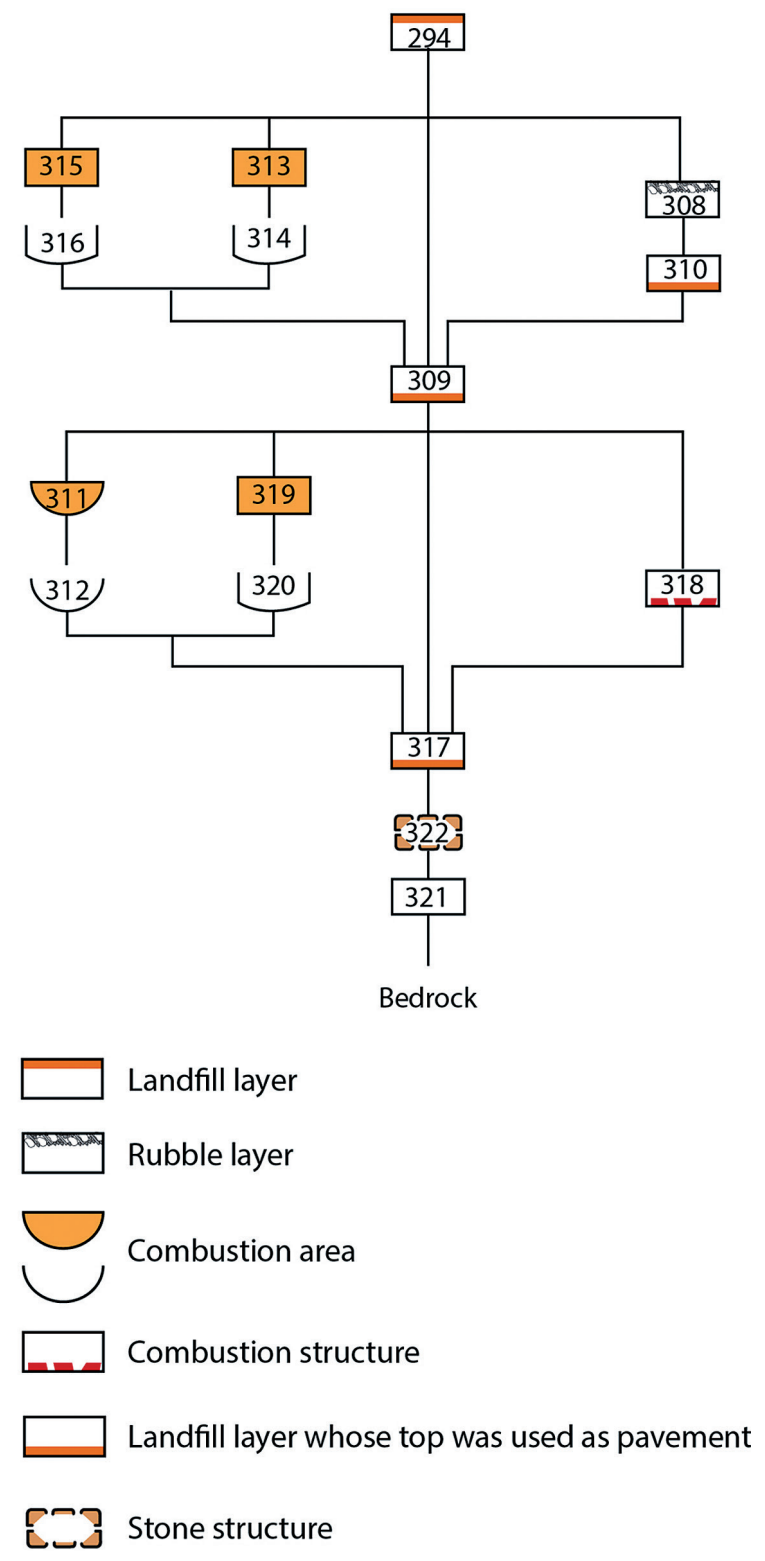

Fig. 4. Alcáçova de Santarém. Stratigraphic matrix of the Late Bronze Age occupation.

\section{THE CERAMIC SET}

In these Late Bronze Age strata we recovered a significant pottery assemblage: 146 diagnostic fragments (117 rims, nine bases, 19 walls and a coroplastic artifact-120 NMI), 98 of which could be classified typologically (Fig. 5). All the fragments are handmade, with the exception of

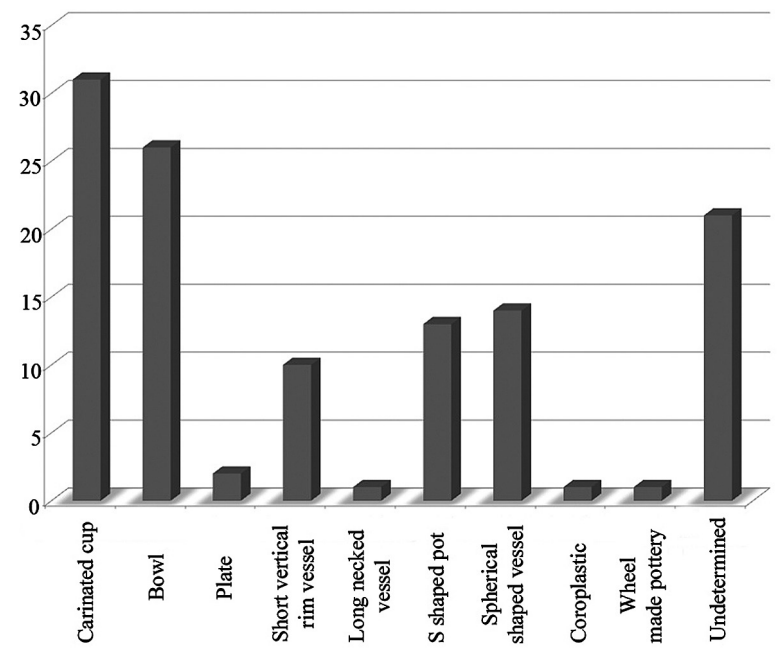

\begin{tabular}{|c|c|c|c|c|c|}
\hline S.U. & {$[\mathbf{2 9 4}]$} & {$[\mathbf{3 0 8}]$} & {$[\mathbf{3 1 0}]$} & {$[\mathbf{3 1 1}]$} & {$[\mathbf{3 1 7}]$} \\
\hline Carinated cup & 19 & 0 & 3 & 1 & 8 \\
\hline Bowl & 6 & 0 & 3 & 0 & 17 \\
\hline Plate & 2 & 0 & 0 & 0 & 0 \\
\hline $\begin{array}{c}\text { Short vertical rim } \\
\text { vessel }\end{array}$ & 1 & 1 & 1 & 0 & 7 \\
\hline Long necked vessel & 0 & 0 & 0 & 0 & 1 \\
\hline S shaped pot & 5 & 1 & 4 & 0 & 3 \\
\hline $\begin{array}{c}\text { Spherical shaped } \\
\text { vessel }\end{array}$ & 1 & 0 & 0 & 0 & 13 \\
\hline Coroplastic & 0 & 0 & 0 & 0 & 1 \\
\hline Wheel made pottery & 1 & 0 & 0 & 0 & 0 \\
\hline Undetermined & 6 & 0 & 2 & 1 & 12 \\
\hline NMI & 41 & 2 & 13 & 2 & 62 \\
\hline
\end{tabular}

Fig. 5. Alcáçova de Santarém. Ceramic types identified among the Late Bronze Age assemblage. Down according to their S.U. (NMI).

a single sherd from the S.U. [294], which can, however, be considered as an intrusion, a problem that we will discuss further ahead.

The handmade pottery often exhibits careful surface treatment, using polishing (NMI 42 - 35.59\%) and smoothing (NMI 68 - 57.63\%) techniques. Only a limited number of fragments display coarser surfaces (8 NMI - 6.78\%). The surfaces of the vessels are mostly plain, though a small group (10 fragments) are decorated using a printing comb, a characteristic technique in the Cogotas I culture. Less common are burnished 
decorations (three fragments), nipple-like protusions (two) and incisions over the rims.

Relating to the general morphology, open forms dominate $(49.17 \%)$ over closed ones (31.67. In addition to the coroplastic artifact $(0.83 \%), 18.33 \%$ of the set could not be assigned to a specific morphological classification, (Fig. 5 down). Among the open vessels, the most frequent type is the small carinated cup with everted rim (31 NMI - 25.83\%) (Fig. 6). Their diameters fall between 93 and $168 \mathrm{~mm}$, a range that matches the ranges registered at contemporary sites in the interior of Portugal (Vilaça 1995: 272-273; Almeida et al. 2012: 234). Morphologically, this group is

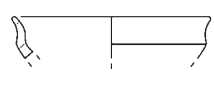

180 [294]

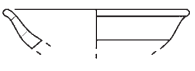

194 [294]
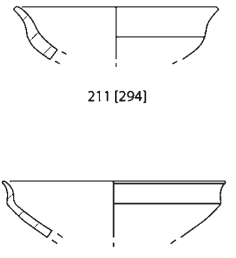

181 [294]

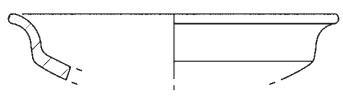

184 [294]

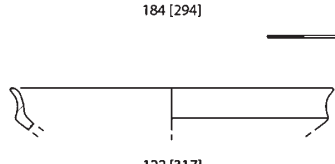

$122[317]$
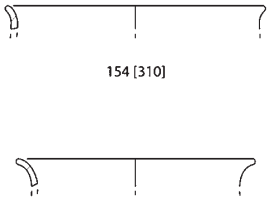

147 [311]
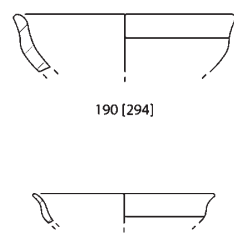

192 [294]
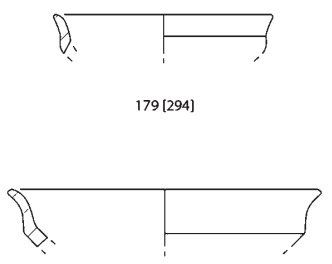

183 [294]

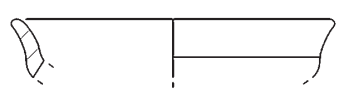

$92[317]$
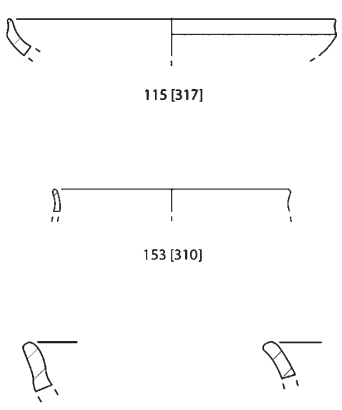

$101[317]$
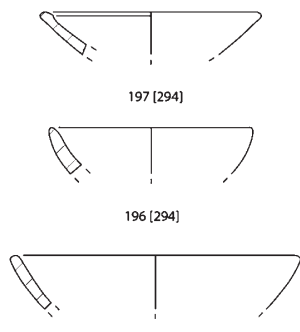

$162[310]$

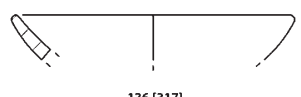

$136[317]$
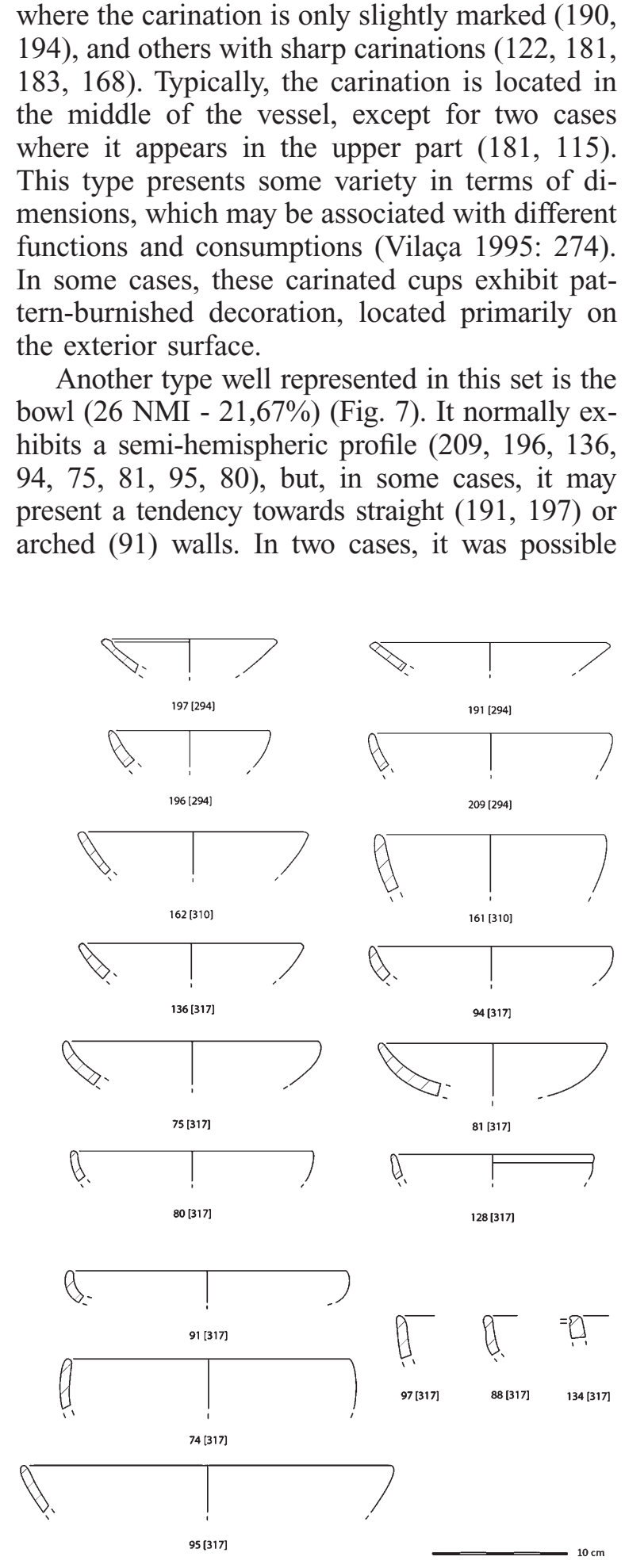
183, 168). Typically, the carination This type presents some variety in terms of dimensions, which may be associated with different the exterior surface.

Another type well represented in this set is the bowl (26 NMI - 21,67\%) (Fig. 7). It normally exhibits a semi-hemispheric profile $(209$, 94, $75,81,95,80)$, but, in some present a tendency towards straight $(191,197)$ or arched (91) walls. In two cases, it was possible

Fig. 7. Alcáçova de Santarém. Bowls of the Late Bronze Age occupation.

Fig. 6. Alcáçova de Santarém. Carinated cups of the Late Bronze Age occupation.

Trab. Prehist., 72, N. ${ }^{\circ}$ 1, enero-junio 2015, pp. 176-187, ISSN: 0082-5638

doi: $10.3989 /$ tp.2015.12150 


\begin{tabular}{|c|c|c|c|c|c|c|c|c|}
\hline & 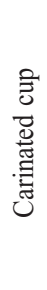 & 容 & $\frac{\frac{D}{\pi}}{2}$ & 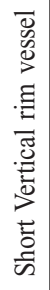 & 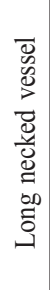 & 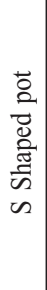 & 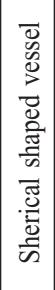 & 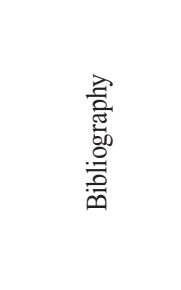 \\
\hline $\begin{array}{l}\text { Alcáçova de } \\
\text { Santarém }\end{array}$ & 31 & 26 & 2 & 10 & 1 & 13 & 14 & \\
\hline $\begin{array}{c}\text { Tapada } \\
\text { de Ajuda }\end{array}$ & + & + & + & + & + & + & + & $\begin{array}{c}\text { Cardoso and } \\
\text { Silva } 2004\end{array}$ \\
\hline $\begin{array}{c}\text { Praça } \\
\text { da Figueira }\end{array}$ & + & + & - & + & + & + & + & Silva 2013 \\
\hline $\begin{array}{c}\text { Serra da } \\
\text { Amoreira }\end{array}$ & + & - & - & - & - & - & - & Marques 1987 \\
\hline $\begin{array}{c}\text { Quinta Nova } \\
\text { de Santo } \\
\text { António }\end{array}$ & + & - & - & - & + & - & + & $\begin{array}{l}\text { Neto } \\
\text { et al. } 2013\end{array}$ \\
\hline Abrunheiro & + & - & - & - & + & + & + & $\begin{array}{c}\text { Cardoso } \\
\text { 2010-2011a }\end{array}$ \\
\hline $\begin{array}{l}\text { Moinho da } \\
\text { Atalaia Oeste }\end{array}$ & + & - & - & - & - & + & - & $\begin{array}{c}\text { Pinto and } \\
\text { Parreira } 1978\end{array}$ \\
\hline $\begin{array}{l}\text { Gruta do } \\
\text { Correio-Mor }\end{array}$ & + & + & - & - & + & + & + & Cardoso 2003 \\
\hline $\begin{array}{c}\text { Castelo } \\
\text { dos Mouros }\end{array}$ & + & - & - & - & - & - & - & $\begin{array}{c}\text { Cardoso } \\
1997-1998\end{array}$ \\
\hline Penha Verde & + & - & - & - & - & - & - & $\begin{array}{c}\text { Cardoso } \\
2010-2011 \mathrm{~b}\end{array}$ \\
\hline Meijão & + & - & - & - & - & - & - & $\begin{array}{c}\text { Kalb and Hock } \\
1985\end{array}$ \\
\hline Tanchoal & - & - & - & - & + & - & - & $\begin{array}{c}\text { Kalb and Hock } \\
1985\end{array}$ \\
\hline $\begin{array}{c}\text { Cabeço } \\
\text { da Bruxa }\end{array}$ & + & - & - & + & - & - & - & $\begin{array}{c}\text { Kalb and Hock } \\
1985\end{array}$ \\
\hline $\begin{array}{c}\text { Cabeço } \\
\text { de Alcainça }\end{array}$ & + & - & + & + & + & + & + & Ponce 2013 \\
\hline $\begin{array}{l}\text { Monte } \\
\text { da Pena }\end{array}$ & + & - & - & - & + & - & - & $\begin{array}{l}\text { Madeira } \\
\text { et al. } 1972\end{array}$ \\
\hline $\begin{array}{c}\text { Moita } \\
\text { da Ladra }\end{array}$ & + & - & - & - & + & - & - & $\begin{array}{c}\text { Monteiro and } \\
\text { Pereira } 2013\end{array}$ \\
\hline $\begin{array}{c}\text { Quinta } \\
\text { do Marcelo }\end{array}$ & + & - & - & - & - & - & - & Barros 1998 \\
\hline
\end{tabular}

Tab. 1. Lisbon's Peninsula Late Bronze Age ceramic repertoire.

to observe the existence of a small groove in the upper external surface $(128,88)$. The rims present mostly a semi-circular section, although in some cases they exhibit a sharper profile. In two other cases, we observe the application of nipple protrusions on the outer surface, along the rim (109, 141). The diameters vary between 153 and 258 $\mathrm{mm}$, values that approach those of ceramic sets from more interior areas (Vilaça 1995: 274). This type of bowl is less frequent among published artifactual collections from the Bronze Age final phase in the Lisbon area, as we can observe in table 1.

Two other fragments (2 NMI - 1.67\%) are shallower, with oblique walls and a semi-circular everted rim. They seem to correspond to some type of dish $(169,171)$, a very rare type in the regional Late Bronze Age repertoire (Fig. 8). Their diameters are 216 and $369 \mathrm{~mm}$.

Among the closed forms, we have identified several fragments that were classified as pots, although they exhibit some noteworthy differences

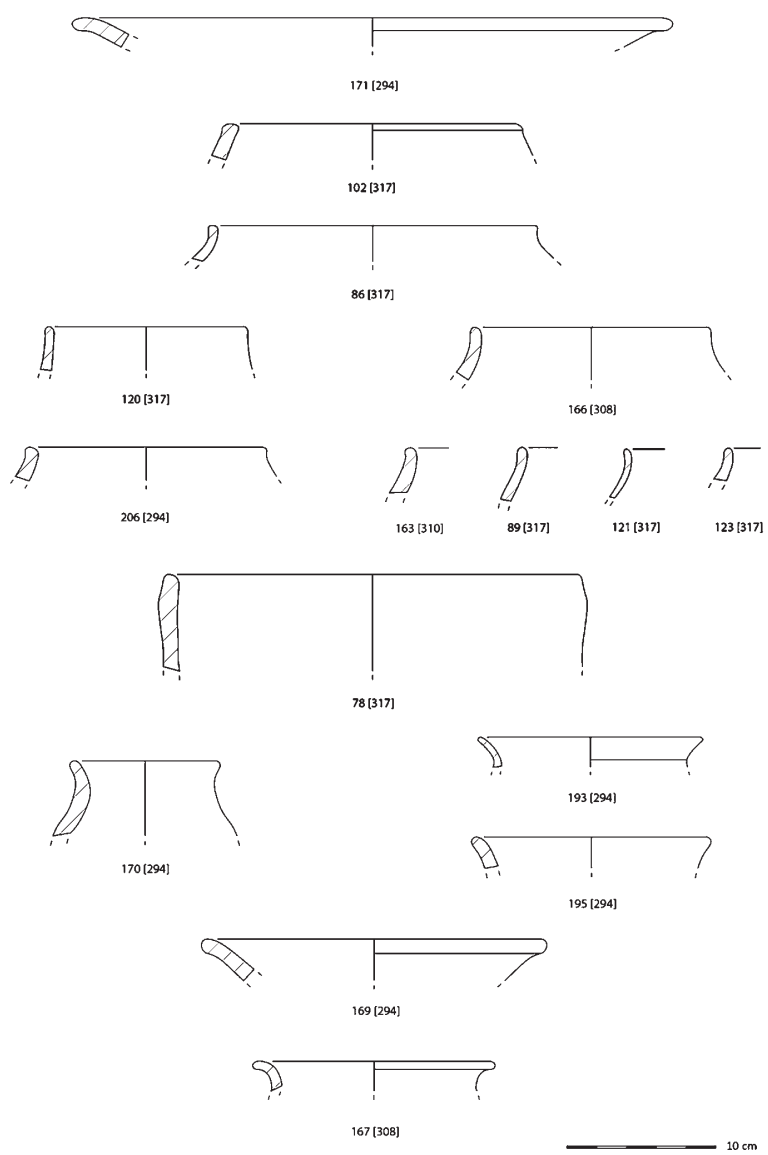

Fig. 8. Alcáçova de Santarém. Plates, short vertical rim vessels, long necked vessels and $\mathrm{S}$ shaped pots of the Late Bronze Age occupation. 
regarding the shape of the rims. A first type (10 NMI $-8.33 \%$ ) has short, vertical and semi-circular section rims and globular or oval vessel shapes $(166,163,206,86,120)$ (Fig. 8). Their diameters vary between 126 and $207 \mathrm{~mm}$. Two of these fragments $(130,83)$ exhibit printed decoration on their external surfaces (Fig. 10). These vessels have a domestic function at Santarém, as well as other sites (Tab. 1), but it should be noted that these vases were used as funerary urns in the nearby necropolis of Alpiarça (Kalb and Hock 1985).

Another vessel (1 NMI - 0.83\%) shows also a vertical and semi-circular rim, followed by a long, rectilinear vertical neck (78) (Fig. 8). Its diameter is $264 \mathrm{~mm}$. Given how much these containers vary in the Tagus estuary region, it is quite difficult to establish an accurate profile based only on small rim fragments (Madeira et al. 1972; Cardoso 2003a; Monteiro and Pereira 2013).

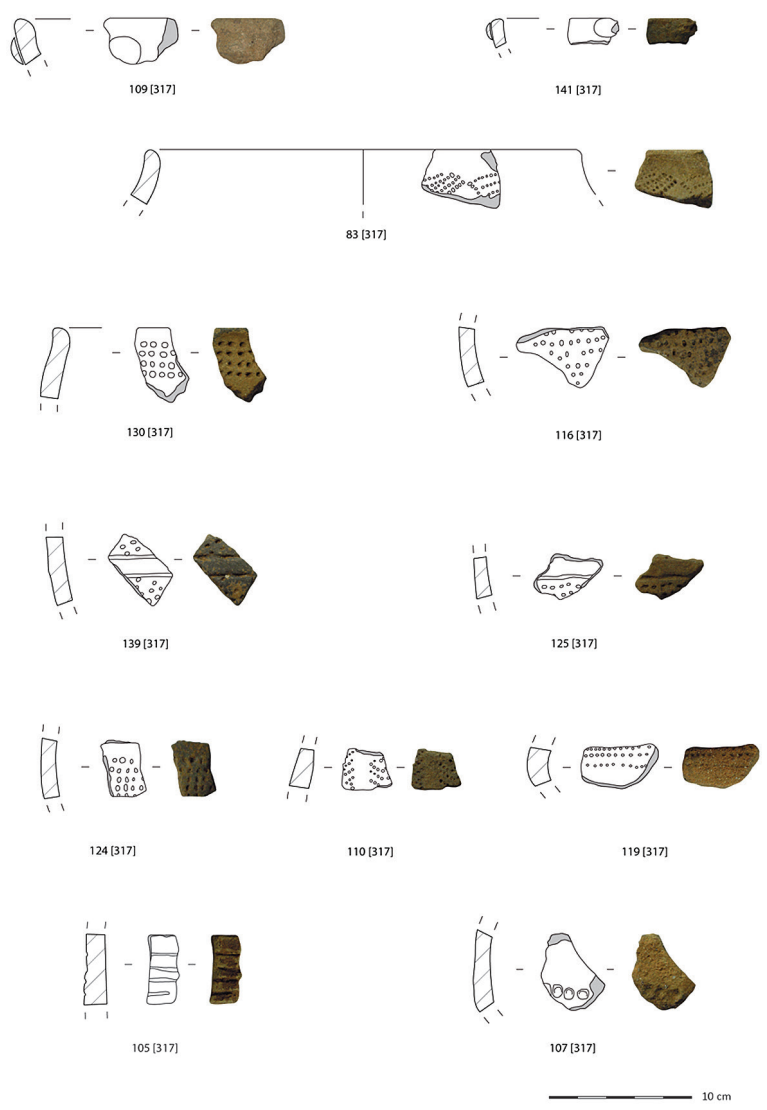

Fig. 9. Alcáçova de Santarém. S shaped pots, spherical shaped vessels and bases of the Late Bronze Age occupation.
Several other fragments were classified as "S shaped" pots, quite frequent in Late Bronze Age contexts of Lisbon Peninsula (Table 1). In Alcáçova de Santarém this type is also well represented (NMI 13 - 10.83\%), exhibiting, in some cases, specific features (Figs. 8 and 9). All share a simple, sub-circular everted rim. The neck is quite variable, sometimes high and vertical (147, $157,158,168)$, and, in other cases, lower and curvilinear $(170,89)$. Their diameters vary between 93 and $222 \mathrm{~mm}$. Two fragments exhibit incised decoration over the rim $(158,172)$.

In addition to these types, we have identified typical Late Bronze Age spherical shaped vessels, with an inverted and semi-circular rim (14 NMI - 11.67\%) (Fig. 9). The body of these vases generally have globular contours, with the exception of a single fragment that exhibits straighter walls (84). Their diameters vary between 141 and $198 \mathrm{~mm}$.

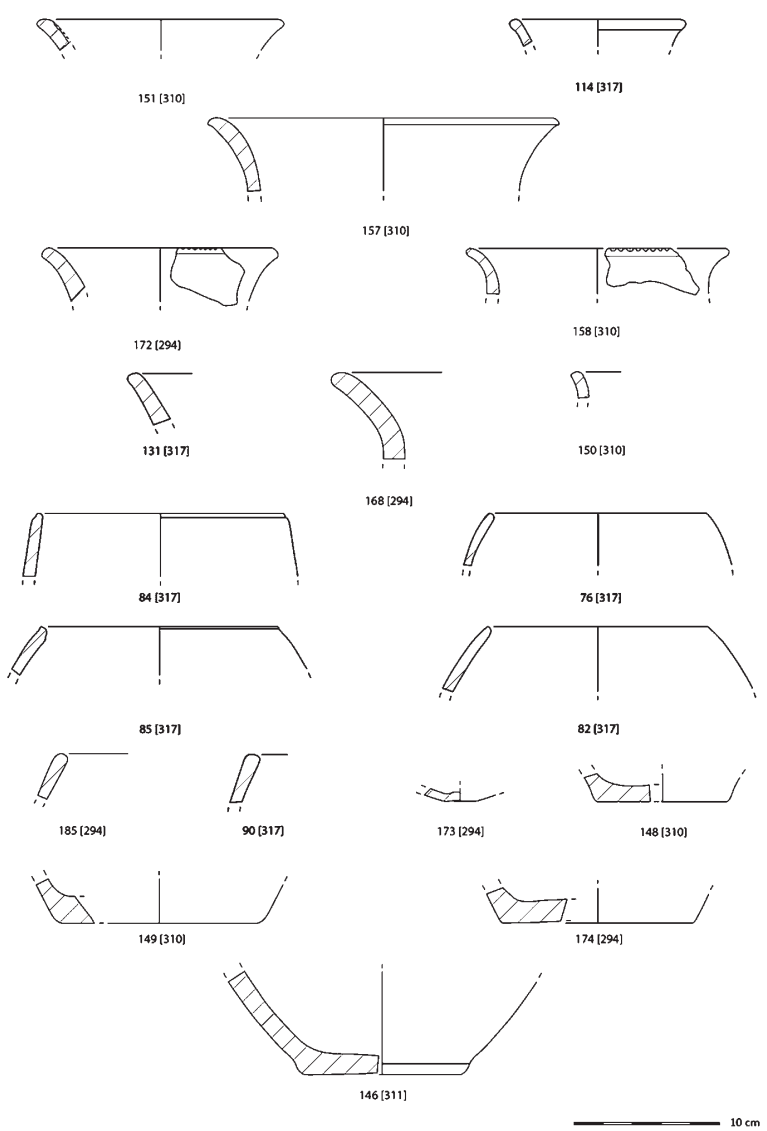

Fig. 10. Alcáçova de Santarém. Decorated fragments of the Late Bronze Age occupation. 
In addition to these fragments, we have also identified several decorated wall sherds. Seven of these exhibit printed decoration on the external surface (more or less deep punctures), applied with semi-circular punches and sometimes associated with incised lines (Figs. 10 and 11). Two pairs of these fragments (124 and 139; 83 and $110)$ probably correspond to a single vase. Although these fragments were small, we observed that in two cases ( 83 and 110), the printed patterns (punctures) are organized into a diamond shape without any incised lines that define them. Some alveoli show residues of a white paste. Two other fragments have digitations (160) (Fig. 11) and nail marks (107) (Fig. 10). Another kind of printed decoration exhibits parallel lines, applied across the body of a carinated cup through the use of some type of comb (216) (Fig. 11).

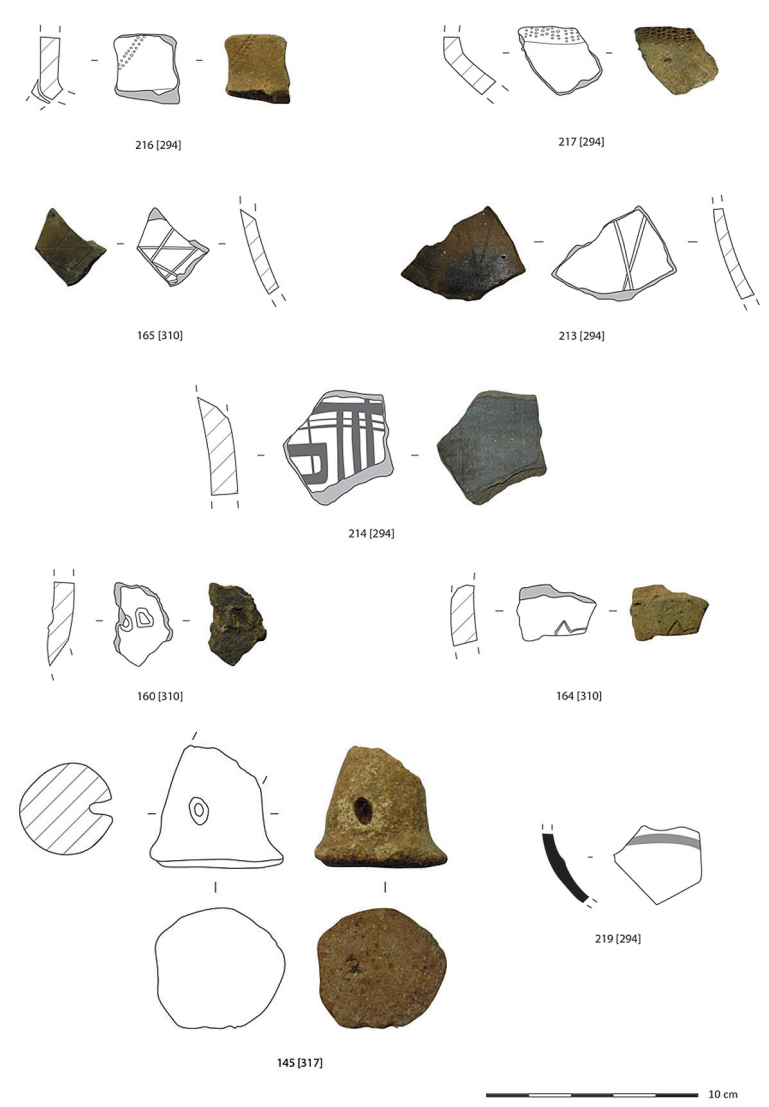

Fig. 11. Alcáçova de Santarém. Decorated fragments, horn idol and wheel made ceramic fragment of the Late Bronze Age occupation.
Burnished decoration was documented in only three fragments (Fig. 11). In two of these, the decoration was applied on the internal surface $(165,213)$ of what seem to be carinated cups. Considering the reduced size of these fragments it is not possible to determine the actual motifs, although existence of reticulated patterns seems likely. They consist of burnished grooves applied on the carefully polished surfaces of finely made vessels.

The external wall of another fragment exhibits decoration (214) that consists of parallel and perpendicular lines and a sub-rectangular motif (Fig. 11).

Finally, three fragments display incised decorations, one of them with several grooves (105) (Fig. 10), another with a broken line (164) (Fig. 11) and the last one (not illustrated) with parallel and oblique lines.

Among the handmade ceramic set we have also identified nine flat bases (1 NMI), with somewhat variable dimensions (Fig. 9).

Also noteworthy is a coroplastic object (NMI $1-0.83 \%$ ), which seems to correspond to a "horn idol" (Fig. 11). It is a massive piece, with a flattened circular base that develops into a curved profile with truncated conical section, and an incomplete perforation in its lower part. Unfortunately, this object is fractured in its upper part, which makes it difficult to determine the exact morphology.

We also must comment on the presence of a wheel made fragment (219) (Fig. 11), painted with a red strip in the external surface (1 NMI $-0.83 \%$ ), which was recovered in the last occupation stratum of the Late Bronze Age (S.U. [294]). Although it could be interpreted as a first token of contacts established between the indigenous community of Alcáçova de Santarém and the Orientalizing world, is not impossible that it corresponds to an intrusion, since a ditch constructed during the Iron Age cuts this stratigraphic unit.

\section{CONSIDERATIONS ON THE CERAMIC SET}

Interpreting the meaning of Alcáçova de Santarém's Late Bronze Age material culture is difficult because it is hard to establish a compar- 
ative framework with other assemblages in Portuguese Estremadura. Until recently, representative ceramic series of this period from excavations were scarce. This is difficult to understand in a region with a remarkably high density of human occupation during the Late Bronze Age. But in fact few archaeological sites of this period have been subject to archaeological excavations that were followed by detailed study of the collected artifacts. In most cases, we only have evidence collected in surveys or old excavations. This makes it very difficult to undertake contextual analyses that could result in a more accurate understanding of the Late Bronze Age in the Portuguese Central Atlantic coast. A rare exception is Tapada da Ajuda, a small rural settlement quite different from and earlier than the hillfort at Santarém, with evidence for both architecture and material culture (Cardoso et al. 1980-1981; Cardoso and Silva 2004). Recently, other ceramic sets from Lisbon (Praça da Figueira, Silva 2013) and Vila Franca de Xira (Moita da Ladra, Monteiro and Pereira 2013) have been published. These provide more and better information towards the definition of the material culture of late $2^{\text {nd }} /$ early $1^{\text {st }}$ millennium BCE.

Regarding the morphological features, we observe remarkable similarities between the Late Bronze repertoire of Alcáçova de Santarém and Lisbon (Tapada da Ajuda and Praça da Figueira). In both carinated cups and bowls predominate, and the characteristics of closed forms (S shaped profile vases, vertical short rim vessels and spherical profile recipients) (Tab. 1) are similar as well. The same situation exists in other areas during the Late Bronze Age, such as Alentejo (Arraiolos -Almeida et al. 2012), Spanish Extremadura (Los Concejilles, Vilaça et al. 2012) and Beira Interior (Vilaça 1995).

A unique aspect of the assemblage of Alcáçova de Santarém is related to the decorative features that occur in a significant, if reduced (circa 5\%), proportion of the pottery ( 23 fragments). The majority of decorated fragments (10 sherds) exhibit punctuated decoration, printed through the use of a punch, that may or may not be organized in diamond shapes, and with or without incised grooves that delineate specific areas. This type of decoration is characteristic of the Cogotas I culture of the Meseta (Figs. 10 and 11). This occurrence is undoubtedly difficult to interpret considering that in the Lisbon area there are few sites with ceramics decorated with this type of technique or motifs. In fact, even though we know that the expansion of these features outside the Cogotas nuclear area was a reality, this does not necessarily translate into an expansion of the territory of Cogotas communities. The truth is that in southern, southwestern and even southeastern Iberia the spread of Cogotas pottery was always very limited and often did not include this specific decorative characteristics. As a matter of fact, the Cogotas I decoration most abundantly reproduced outside the nuclear area was, undoubtedly, the "boquique" type, which is not documented at Santarém.

A similar situation is documented in a nearby area, specifically at the site of Quinta da Aramenha, in Cartaxo, where the absence of "boquique" is also evident, although in this case, along with punctuated decoration, there are also vases decorated with wavy lines, apparently printed through the use of a comb (Tereso and Ferreira 2007).

In Alentejo, the Cogotas influences are limited to a few fragments decorated with printed dots recovered at Passo Alto (Soares et al. 2012). The same situation occurs in Spanish Extremadura, at Los Concejilles, for example, where fragments also decorated with printed dots, some of them with residues of white paste, were recovered along with others with combed and incised decoration (Vilaça et al. 2012), and also at Medellín (Jímenez Avila and Guerra Milán 2012). We should underline, however, the absence of the "boquique" technique in all of the above-mentioned sites. Thus, even if the "punto y raya" decor occurs (and it is always rare) quantities, the truth is that in Spanish Extremadura and Alentejo these attestations do not appear to be contemporary to the ones discussed in this paper.

Also made by printing and somehow related to the same chronological and cultural universe (and thus with parallels in these same sites) are the cases of fragments decorated with digitations and nail marks (Figs. 9 and 11), as well as those decorated with incisions on the external surface and over the rim (Figs. 9, 10 and 11).

The rarity of ceramics with burnished decoration (three fragments) (Fig. 11) also should be underlined, considering that the settlements of Alentejo and Spanish Extremadura exhibit a higher frequency of these decorative techniques. 
Also in the Portuguese Estremadura, the decorated ceramics of the Late Bronze Age include, almost exclusively, burnished motifs, with the exception of those with incised decorations over the rim. However, we should recall that in Aramenha (Cartaxo) burnished decoration is also absent (Tereso and Ferreira 2007), an indisputable fact that we should relate to our data.

Interestingly, in two fragments of Santarém, the burnished decoration is applied in the internal surface (Fig. 11), a relatively rare occurrence in the Portuguese Estremadura. There, as in the Setúbal Peninsula, and even Alentejo, these motifs appear in the external surface of the vessels. Anyway, we should highlight the fact that, in both cases, we are dealing with burnished grooves that define triangles or diamonds, and not with "burnished ornaments", a type of decoration that is documented, some times even on wheel made pottery, in the later, Iron Age levels of Santarém (Arruda 1999-2000).

The vase decorated with "burnished ornaments" on the outside wall is less challenging to interpret, considering that this technique is quite common in the regional context (Fig. 11).

With the exception of the carinated cup recovered in Quinta do Marcelo, we know no other example of vases with internal burnished decoration in Estremadura, a phenomenon that is more typical in interior areas of Iberia, and almost always applied with "burnished ornaments", such as occurs in Alentejo and the Guadalquivir valley.

The "horn idol" (Fig. 11) is more difficult to interpret in this context, considering that the type of artifact is common in wider areas of central and southern Portugal, even if during a considerably older time period. However, we should underline a significant presence of these objects in Estremadura, even if always associated with Chalcolithic occupations. On the other hand, the discussion concerning the function of these artifacts centers on whether they are related to activities of a magical religious kind (Gonçalves 1989; Rodrigues 2013) or of a domestic/utilitarian kind (Cardoso 2003b). The Santarém "horn idol" was found near a combustion area, which may indicate the latter function. To this is added a chronological factor, since it becomes difficult to admit an extension of Neolithic and Chalcolithic worshiped entities until end of the Bronze Age.

\section{DISCUSSION}

The data concerning the Late Bronze Age occupation of Alcáçova de Santarém deserve to be discussed in terms of its regional context.

In first place, we should outline the connection to the Meseta, sustained by the presence of the "Cogotas style" decorated fragments, a type of evidence that is practically unknown in the Lisboa Peninsula, with the exception of Quinta da Aramenha in Cartaxo (Tereso and Ferreira 2007). However, this link seems to be a perpetuation of a previous scenario, although to a lesser extent. As a matter of fact, in the Lisbon Peninsula, only Gruta do Correio-Mor provided material related to Meseta world, namely a fragment decorated with incised or printed stalks (Cardoso 2003a). On the other hand, the river certainly contributed towards the contact between the lower and upper Tagus, even if the presence of the Cogotas world is also quite rare at settlements such as Monte do Frade and Moreirinha excavated by Raquel Vilaça (1995) in Beira Interior, and practically inexistent in Upper Ribatejo. The "boquique" decorated fragments of Alvaiázere can only faintly be related to this "route" (Félix 2006).

The fact that the decorated ceramics recovered in Santarém relate more to the Cogotas I world than to the regional scenario of Lisbon Peninsula is undoubtedly strange, and only future field interventions, carried out in extension and conducted under modern methodologies in this last area may clarify this apparent paradox.

The chronology of this Late Bronze Age occupation can be placed in the transition between the $2^{\text {nd }}$ and the $1^{\text {st }}$ millennium BCE, and more likely at the beginning of the latter. This proposal is corroborated not only by the analysis of the artifacts recovered but also by the stratigraphic sequence of Alcáçova de Santarém, considering that other Iron Age levels, identical to the ones that overlap this Late Bronze Age occupation, were dated by radiocarbon between the $9^{\text {th }} /$ early $8^{\text {th }}$ century BCE (Arruda 1993; Arruda 1999-2000) (Tab. 2).

Finally, we should underline that Alcáçova de Santarém is a rare example of a Late Bronze Age settlements of the Portuguese Estremadura whose occupation continued without any gap through the Iron Age. The resistance and/or the collaboration with the Phoenicians groups who arrived in the Tagus estuary is clear, unlike what occurred at 


\begin{tabular}{|c|c|}
\hline UE 15 & C.V. 1 \\
\hline Beta 131488 & ICEN 532 \\
\hline $2650 \pm 70$ & $2640 \pm 50$ \\
\hline Crb & Crb \\
\hline $\begin{array}{c}\text { Arruda 1999-2000: } \\
217-218\end{array}$ & Arruda 1993: 198 \\
\hline
\end{tabular}

Tab. 2. Radiocarbon dates for Alcáçova de Santarém early Iron Age occupation.

most sites in the region, as well as in other geographical areas.

\section{AKNOWLEDGMENTS}

This work was carried out through the project "Fenícios no Estuário do Tejo": PTDC/EPHARQ/4901/2012

\section{BIBLIOGRAPHY}

Almeida, S.; Silva, R. and Osório, A. 2012: "O povoado de S. Pedro de Arraiolos (Alentejo, Portugal). Novos dados para o seu conhecimento". En J. Jiménez Ávila (ed.): Sidereum Ana II. El río Guadiana en el Bronce Final. Anejos de Archivo Español de Arqueología LXII, CSIC. Madrid: 229-248.

Arruda, A. M. 1993: "A ocupação da Idade do Ferro da Alcáçova de Santarém no contexto da expansão fenícia para a fachada atlântica peninsular". Estudos Orientais 4: 193-214.

Arruda, A. M. 1999-2000: Los Fenicios en Portugal. Fenicios y mundo indígena en el centro y sur de Portugal (siglos VIII-VI a.C.). Cuadernos de Arqueología Mediterránea 5-6. Barcelona.

Arruda, A. M. 2005: "O $1^{\circ}$ milenio a.n.e. no Centro e no Sul de Portugal: leituras possíveis no início de um novo século". O Arqueólogo Português 4-23: 9-156

Arruda, A. M. and Viegas, C. 2002: "A Alcáçova". In De Scallabis a Santarém. Museu Nacional de Arqueologia. Lisboa: 73-81.

Barros, L. 1998: Introdução à Pré e Proto-História de Almada. Cámara Municipal de Almada.

Cardoso, J. L. 1997-1998: “O povoado do Bronze Final do Castelo dos Mouros". Estudos Arqueológicos de Oeiras 7: 169-177.

Cardoso, J. L. 2003a: "A gruta do Correio-Mor (Loures)". Estudos Arqueológicos de Oeiras 11: 229-321.
Cardoso, J. L. 2003b: “Ainda sobre os impropriamente chamados 'Ídolos de Cornos' do Neolítico Final e do Calcolítico da Estremadura e do Sudoeste". Al'Madan 2 (12): 77-79.

Cardoso, J. L. 2010-2011a: "O casal agrícola do Bronze Final de Abrunheiro (Oeiras)". Estudos Arqueológicos de Oeiras 18: 33-74.

Cardoso, J. L. 2010-2011b: "A ocupação do Bronze Final do povoado pré-histórico da Penha Verde (Sintra)". Estudos Arqueológicos de Oeiras 18: 579-590.

Cardoso, J. L.; Roque, J.; Peixoto, F. and Freitas, F. 1980-1981: "Descoberta de jazida da Idade do Bronze da Tapada da Ajuda". Setúbal Arqueológica 6-7: 117-147.

Cardoso, J. L. and Silva, I. M. 2004: "O povoado do Bronze Final da Tapada da Ajuda (Lisboa): estudo do espólio ceramic". Revista Portuguesa de Arqueologia 7 (1): 227-271.

Félix, P. 2006: "Os finais da Idade do Bronze e inícios da Idade do Ferro no Ribatejo norte (Centro de Portugal). Uma breve síntese dos dados arqueográfiogicos". Conímbriga 45: 65-92.

Gonçalves, V. 1989: Megalitismo e Metalurgia no Alto Algarve Oriental. Centro de Arqueologia da Universidade de Lisboa. Lisboa.

Jiménez Ávila, J. and Guerra Milán, S. 2012: "El Bronze Final en Medellín. Estudio preliminar del Corte SMRO”. En J. Jiménez Ávila (ed.): Sidereum Ana II. El río Guadiana en el Bronce Final. Anejos de Archivo Español de Arqueología LXII, CSIC. Madrid: 65-110.

Kalb, P. and Hock, M. 1985: Cerâmica de Alpiarça. Catálogo. Câmara Municipal de Alpiarça. Alpiarça.

Madeira, J.; Gonçalves, J. L.; Raposo, L. and Parreira, R. 1972: "Achados da Idade do Bronze no Monte da Pena (Barro/Torres Vedras) - Notícia prévia". $O$ Arqueólogo Português 3 (6): 207-212.

Marques, G. 1987: "Aspectos da proto-história do território português, III - Castelo da Amoreira (Odivelas - Loures)". Boletim Cultural de Loures 1: 51-58.

Monteiro, M. and Pereira, A. 2013: "Um depósito votivo da Idade do Bronze na Moita da Ladra (Vila Franca de Xira): Síntese dos trabalhos realizados e resultados preliminaries". Cira-Arqueologia 2: 63-94.

Neto, N.; Gonzalez, C.; Rebelo, P.; Santos, R. and Rocha, M. 2013: "Trabalhos arqueológicos na Quinta Nova de Santo António ou dos Ingleses - Carcavelos. A ocupação do Bronze final". Cira-Arqueologia 2: 19-39.

Pinto, C. V. and Parreira, R. 1978: "Contribuição para o estudo do Bronze Final e do Ferro Inicial a norte do Estuário do Tejo". Actas das III Jornadas da Associação dos Arqueólogos Portugueses (Lisboa 1977): 147-163.

Ponce, M. 2013: O Bronze Final na Península de Lisboa. O caso do Cabeço de Alcainça na transição entre o $2^{\circ}$ e o $1^{\circ}$ milénio a.C. Tese de mestrado apresentada à Faculdade de Letras da Universidade de Lisboa. Lisboa. http://hdl.handle.net/10451/9936. 
Rodrigues, F. 2013: "Ídolomania: figuras antropomórficas e "ídolos de cornos" do recinto de fossos do Neolítico final da Ponte da Azambuja 2 (Portel, Évora)". In J. M. Arnaud, A. Martins and C. Neves (eds.): Arqueologia em Portugal. 150 anos (Lisboa, 2013): 435-446. Lisboa.

Silva, R. B. 2013: "A ocupação da idade do bronze final da Praça da Figueira (Lisboa): novos e velhos dados sobre os antecedentes da cidade de Lisboa". Cira - Arqueologia 2: 40-102.

Soares, A. M.; Antunes, A. S. and Deus, M. 2012: “O Passo Alto no contexto dos povoados fortificados do Bronze Final do Sudoeste". In J. Jiménez Ávila (ed.): Sidereum Ana II. El río Guadiana en el Bron- ce Final. Anejos de Archivo Español de Arqueología LXII, CSIC. Madrid: 249-276.

Tereso, S. and Ferreira, S. 2007: "O povoado proto-histórico da Quinta da Aramenha (Santana, Cartaxo)". Revista Portuguesa de Arqueologia 10 (1): 179-208.

Vilaça, R. 1995: Aspectos do povoamento da Beira Interior (Centro e Sul) nos finais da Idade do Bronze. Instituto Português de Arqueologia. Lisboa.

Vilaça, R.; Jiménez Ávila, J. and Galán Domingo, E. 2012: "El poblado de Los Concejiles (Lobón, Badajoz) en el contexto del Bronce Final del Guadiana

Medio". In J. Jiménez Ávila (ed.): Sidereum Ana II. El río Guadiana en el Bronce Final. Anejos de Archivo Español de Arqueología LXII, CSIC. Madrid: 125-168. 